\title{
SOFT POWER, CONFUCIUS INSTITUTE AND CHINA'S CULTURAL DIPLOMACY IN MALAYSIA
}

\section{Ngu Ik Tien ${ }^{*}$ and Ngeow Chow Bing ${ }^{2}$}

\author{
${ }^{1}$ Department of Chinese Studies, Faculty of Arts and Social Sciences, University \\ of Malaya, Kuala Lumpur, MALAYSIA \\ ${ }^{2}$ Institute of China Studies, University of Malaya, Kuala Lumpur, MALAYSIA \\ *Corresponding author: tngu@um.edu.my
}

Published online: 30 April 2021

To cite this article: Ngu Ik Tien and Ngeow Chow Bing. 2021. Soft power, Confucius institute and China's cultural diplomacy in Malaysia. Kajian Malaysia 39(1): 55-76. https://doi.org/10 $.21315 / \mathrm{km} 2021.39 .1 .3$

To link to this article: https://doi.org/10.21315/km2021.39.1.3

\begin{abstract}
The point of departure in this study is to assess the effectiveness of China's cultural diplomacy in Malaysia by looking at the employment of three main strategies and its limitations. The study utilises the methods of interview and empirical case study by firstly, giving a detailed look into the Kong Zi Institute (Confucius Institute) in Malaysia, and secondly, investigating some rarely-noticed diplomatic undertakings from the provincial or city governments of China. While the Confucius Institute and some image-building efforts represents the aspect of China's central government's soft power policy in Malaysia, the Chinese officials from local governments tend to focus on cultural and economic initiatives with the ethnic Chinese social organisations in Malaysia. After examining the Kong Zi Institute and discussing China's provincial-local governments' cultural outreach activities, the third aspect that this article examines is the narrative of Chinese Dream propagated by the Chinese officials in Malaysia. The article ends with an assessment of Malaysian perceptions and responses towards the Chinese official initiatives. Overall, the impact of China's cultural diplomacy, either the Confucius Institute or other initiatives, in raising the positive image of China, may not be said to be either a success or failure. Malaysian's positive image of China may have been caused by other factors not directly related to China's cultural diplomacy,
\end{abstract}


but other factors, including the foreign policy of China and the remarkable economic achievement.

Keywords: Confucius Institute, cultural diplomacy, soft power, China's image, Malaysia-China relations

\section{INTRODUCTION}

The "soft power" concept is most closely associated with the American scholar, Joseph Nye. In the early 1990s, Nye used the term "co-optive power" to describe the ability to "rest on the attraction of one's ideas" or "the ability to set the political agenda in a way that shapes the preferences that others express" (Nye 1990, 31). Later, he elaborated further and re-termed the concept as "soft power" and argued that there are three soft power resources - culture, political values and foreign policies (Nye 2005). Culture (at both the popular and high levels) increases one's likeability, shared political values enhance one's ability to shape rules and agenda in the international arena, and a just foreign policy reinforces one's credibility. His 2005 book, Soft Power, was particularly popular and the concept found a widespread appeal among policymakers within both the United States and outside, many of them believed that government should formulate effective soft power policies. However, Nye sounded a more cautious note about how the concept has been used and misused, and governmental policies to shape and project soft power do not easily and necessarily translate into the expected results (Nye 2011, 81-109).

Nevertheless, in the mid-2000s, Chinese official and academic circles picked up this idea of soft power and saw its usefulness to complement its rising status as a rising global power. The Chinese government embarked on an expansive programme of cultural diplomacy to strengthen Chinese soft power, including the establishment of over 700 Confucius Institutes or Classrooms abroad, internationalisation of the Chinese media (China Global Television Network, Phoenix Media, China Daily, Xinhua News Agency, China Radio International) in both Western and developing worlds, organising of China-themed festivals in foreign capitals, initiating a "branding" strategy for its cultural products, granting more scholarships for foreign students to study in China, and so forth (Guo 2013, 181-191). Economic diplomacy, especially in the form of the massive infrastructure-focused Belt and Road Initiative pursued by the Chinese government under President Xi Jinping, addresses the infrastructure weaknesses in many developing countries while also reminding these countries of the successful China Model and its ability to reduce acute poverty, improve livelihood, 
and generate substantial material gains for the people. China also attempted to convince the world that its extraordinary rise will be a "peaceful rise": Its foreign policies will not be seeking dominance or hegemony, but instead will seek mutual benefit and "win-win" cooperation, to the eventual realisation of the lofty vision of a "community of shared destiny."

Establishing and projecting Chinese soft power is therefore very much the major rationale for the setting-up of Confucius Institutes by the Chinese government. There is no hidden agenda, as Chinese academic discourses on Confucius Institutes do not shy away in pointing out the strategic importance of this tool of cultural diplomacy (Guo 2013; Wu 2013; Dai 2013). For example, Chinese scholar, Dai Rong $(2013,103)$ wrote that “Confucius Institutes are part of China's national soft power strategy; hence the global setting up of these Institutes should be guided by the national strategic theme of Peace and Development, in the service of the development and interests of China in the world." In addition, it should also be pointed out that similar endeavours have long been undertaken by established powers in the developed world. For instance, the British Council, the Goethe Institute, Lincoln Resource Center, Alliance Française and Japan Foundation are some of the prominent examples. Even South Korea, a middle power, has established the Korea Foundation to promote Korea-related activities for the purpose of enhancing Korean soft power. In this sense, China is only a latecomer.

However, what differentiates the Confucius Institute is its embedded status in the partnering institutions in the host countries. At times, this has created controversies especially in the West as it is seen as related to issues of academic freedom. Due to the Confucius Institute's status as a part of Chinese cultural diplomacy, its relatively short existence has already generated dozens of scholarly articles, books and dissertations. This growing literature on the Confucius Institute can be grouped into different kinds. The first group of literature is generally of introductory in nature, detailing the rationale of the Chinese government (Joseph Nye and soft power generally featured here), the structure and financing of the whole enterprise, with particular emphasis on the role of Hanban (the national headquarters of the Confucius Institutes of the State Council of China), and the fierce debate that Confucius Institutes have generated (Starr 2009; Paradise 2009; Hartig 2012; Pan 2013).

The second group of literature is largely polemical, portraying the Confucius Institute as a highly suspicious and freedom-undermining venture, promoted by an authoritarian state that will post challenges to the democratic values and institutions, especially if the hosting institutions are in democratic countries 
(Shalins 2014; Hughes 2014). Hughes, for example, listed down these negative impacts of Confucius Institutes on hosting universities such as discriminatory employment policy, promoting Chinese propaganda, surveillance over Mainland Chinese students, distortion of academic agenda, negative impact on existing Sinological community and scholars, and self-censorship (Hughes 2014, 62-67).

The third group usually takes a more empirical stand, undertaking detailed singleor comparative case studies of the operation, financing, personnel, relations with the local communities (including indigenous political elite and ethnic Chinese communities), impacts, and other aspects of Confucius Institutes in one or several countries (Hsiao and Yang 2014; Nguyen 2014; Thung 2014; Kornphanat 2016). Comparative studies yield insight into the different contexts faced by Confucius Institutes operating in different countries. Hsiao and Yang (2014), for example, find the Confucius Institutes being enthusiastically welcomed by the Cambodians but not so in the case of Myanmar, despite the governments of Cambodia and Myanmar both being closely aligned to China. The crucial variable seems to be the perceptions of the indigenous political elite towards their ethnic Chinese minorities when the Confucius Institute was set up in their countries.

This article will follow the empirical case study approach as well as interviews with key leaders in examining China's cultural diplomacy, in particular, the Kong $\mathrm{Zi}$ Institute (Confucius Institute), in Malaysia. However, in addition to the Kong $\mathrm{Zi}$ Institute, the article also takes note of the developments of other efforts aimed to increase Chinese soft power, such as the build-up of ties at the subnational level, and the branding narrative of China's central government in promoting Chinese Dream. It is to be noted here also that the bulk of this research was undertaken in 2014-2017, before the change of government in Malaysia that occurred in May 2018. However, the authors do believe that the fundamental dynamics identified in this article are likely to continue. The article ends with an assessment of Malaysian perceptions and responses towards the Chinese official initiatives.

\section{MALAYSIA-CHINA RELATIONS: A BRIEF ACCOUNT}

Political suspicion clouded relations between China and Malaya/Malaysia for the most part of the 20th century. When the Chinese Communist Party took power in Mainland China in 1949, Malaya was still under British colonial rule and her foreign affairs came under London's control. Malaya's China policy came to be shaped by the Emergency which was declared just a year before Beijing came under communist rule. The Emergency was declared by the colonial government to combat the military insurgency mounted by the Communist Party of Malaya 
(CPM), which was widely believed to have received support from the Chinese Communist Party. Furthermore, armed members of the CPM were mostly ethnic Chinese. During the 12-year Emergency, the British Military introduced the Briggs Plan which resettled about 500,000 Malayans of largely Chinese descent to designated areas called "New Villages." The programme was aimed at cutting off contact between those in the New Villages and the insurgency. The residents of the "new villages" were under government surveillance in terms of their mobility, social contact and organisational life. ${ }^{1}$

Malaysia-China relations only began to improve following the visit of the second Prime Minister of Malaysia, Tun Abdul Razak, to Beijing in 1974, which established official diplomatic relations. However, political suspicion between two countries persisted throughout the 1980s. Nonetheless, there was a sense of economic pragmatism as well, especially after the advent of opening up and reform of China under the leadership of Deng Xiaoping since the late 1970s. Economic pragmatism became increasingly more influential in Malaysia's policy towards China during the second half of the 1980s (Kuik 2010).

Since the 1980s, the image of China in the local media that has emerged was more that of an economic power rather than a communist country. The 1985 visit of the fourth Prime Minister of Malaysia, Dr. Mahathir Mohamad, to China gained wide coverage particularly in the local Chinese media. The media highlighted that businessmen from the two major local Chinese and Malay Chambers of Commerce made up a significant component of the delegation of 200 members accompanying the prime minister. Several bilateral economic agreements were signed during and after Mahathir's visit. Of these, the lifting of restriction on business travel to China in late 1980 s was particularly significantly and was welcomed by local business people.

The post-Cold War years saw the greatest improvement in the bilateral relationship. The laying down of arms by the CPM removed one last obstacle to bettering bilateral relations. Since the 1990s, the Malaysian government also lifted restrictions of travel to China. Engagement in the sensitive military-tomilitary diplomacy also began from the early 1990s. The Chinese policy in the 1997 Asian Financial Crisis also earned wide applause and appreciation by the Malaysian government at that time, substantially improving its image, reliability and likeability.

Economic ties remain the strongest foundation between the two countries, with China now being Malaysia's largest trade partner since 2009. Also, since 2000s, the Chinese government has undertaken several cultural and educational projects 
to promote hanyu or Mandarin and Chinese culture and these have added another dimension to Malaysia-China interaction. In addition, China also sent numerous cultural and educational groups of scholars, artists, educationists and officials to visit local social organisations in Malaysia, such as the Malaysian Chinese Chamber of Commerce, traditional Chinese associations, educational institutions and cultural groups. Many of these visits were sponsored by provincial, district and city governments and governmental bodies. Today, despite the overlapping claims of some islands, reefs and atolls in the South China Sea, and despite the change of government in May 2018, China-Malaysia relations remain stable and positive overall.

\section{KONG ZI INSTITUTE AND THE MANAGEMENT OF CULTURAL DIPLOMACY}

China's government has taken the lead in the cultural exchange between China and Malaysia. Hanban, which is the colloquial abbreviation for the Office of Chinese Language Council International, is an agency in the State Council of China responsible for the establishment, financing and management of Confucius Institutes worldwide. As of 2017, official statistics suggest that there are 465 Confucius Institute and 713 Confucius Classrooms throughout the world. Each Confucius Institute plays the role of franchiser in distributing products such as language learning materials and other resources; and it also manages language courses and cultural programmes such as han yu qiao (Mandarin bridge) competition and certifies the language competency of non-Chinese speakers through administering the Chinese Proficiency Test (called the HSK Test). In addition, a notable feature of these institutes is, with a few exceptions, their establishment within universities or other institutions of higher learning in host countries. Usually, the hosting university also has a partner university from China. Other parties, such as private investors, occasionally join in as well.

As indicated in Table 1, Malaysia is behind Thailand, Indonesia and the Philippines in terms of the number of Confucius Institutes, Confucius Classrooms and registered students, among Southeast Asian countries. The founding process of a Confucius Institute in Kuala Lumpur took several years to complete. As early as in 2006, with the approval of Hanban, the very first Confucius Institute in Malaysia was established. It was a collaborative partnership between a private local educational centre and a Shanghai-based Chinese university. A few years later, the local partner lost the status due to some unsolvable disagreements with Hanban. Meanwhile, Chinese officials showed interest to set up a Confucius Institute on the campus of University of Malaya, the oldest and most prestigious 
university in Malaysia. When the idea was proposed to the Malaysian government, the latter took some years to consider the proposal and finally approved it with certain conditions. Among others, there was a request to modify the name of Confucius Institute on the ground that it may denote the religion of Confucianism to Muslims who account for the majority of the population. ${ }^{2}$ After negotiations, Hanban agreed to replace the name with Kong $\mathrm{Zi}$ Institute for the Teaching of Chinese Language at the University of Malaya. The Chinese name of the Institute also was added the word hanyu to become Kongzi hanyu xueyuan. It was launched in 2009. The second Confucius Institute was launched in November 2015, hosted by SEGI University College, a private institution of higher learning. In 2019, two more Confucius Institutes were established, at Universiti Malaysia Pahang and Universiti Malaysia Sabah. However, this article will primarily focus on the Kong $\mathrm{Zi}$ Institute the University of Malaya, due to its pioneering status and long years of operation.

Table 1: Confucius Institutes and Confucius Classrooms in Southeast Asia in 2015

\begin{tabular}{lcccc}
\hline Country & $\begin{array}{c}\text { Confucius Institutes } \\
(\mathrm{CI})\end{array}$ & $\begin{array}{c}\text { Confucius Classrooms } \\
(\mathrm{CC})\end{array}$ & $\begin{array}{c}\text { Sum of CI } \\
\text { and CC }\end{array}$ & $\begin{array}{c}\text { Number of } \\
\text { registered students }\end{array}$ \\
\hline Malaysia & 2 & 0 & 2 & 2,709 \\
Singapore & 1 & 2 & 3 & 13,727 \\
Thailand & 15 & 18 & 33 & 187,831 \\
Indonesia & 6 & 2 & 8 & 10,630 \\
Philippines & 4 & 3 & 7 & 45,409 \\
Brunei & 0 & 0 & 0 & 0 \\
Vietnam & 1 & 0 & 1 & .a. \\
Cambodia & 1 & 3 & 4 & 14,180 \\
Laos & 1 & & 1 & 3,834 \\
Myanmar & 0 & 3 & 3 & 14,509 \\
\hline
\end{tabular}

Source: Confucius Institute Headquarters (Hanban) (2015); n.a. - not available

University of Malaya's partnering institution in China is Beijing Foreign Studies University (BFSU). BFSU is one of the strongest Chinese universities in terms of establishing Confucius Institute partnerships. ${ }^{3}$ Incidentally, BFSU is also one of the institutions in China that offers Malay-language courses leading to a degree in Malay Studies. This is particularly appealing to the Malays as the Malay language has always been seen as a core element in Malay identity and Malay nationalism. The relationship between BFSU and Malaysia is also well grounded in the person of Professor Wu Zongyu, the founder of the Malay language programme in BFSU and one of the earliest Chinese scholars 
to master the language, and who also enjoys very good relationships with many high-level civil servants and politicians in Malaysia. The Malaysian Ministry of Education even honoured him with the publication of a book devoted to his life and work (Awang 2011). BFSU has the support of the Chinese government in strengthening the Malay studies programme and has also in the past launched several international conferences on Malay studies, and the most recent one, held in 2014, was attended by the 6th Prime Minister of Malaysia while he was visiting China officially. The conference drew more than 200 paper presenters and was widely covered in the Malay-language presses in Malaysia, which yielded a positive image of China as a big country that respects and takes seriously the culture and language of a smaller country. This was contrasted with the Western countries that seem always interested to export their own language and culture but not interested to learn from others.

The physical outlook of the Kong Zi Institute building - green in colour, while no Confucius statue is installed, unlike the Confucius Institutes that one of the present authors has visited in Bangkok, Thailand. After entering the front door of the institute, one will have to pass through a veranda where four colourful pictures hang on wall, selectively telling the development of Malaysia-China diplomatic relations from the ancient times to more contemporary periods. It is a reiteration of the official narrative and shows pictures of Malaysia-China encounters centring on the Cheng Ho's voyages (and Melaka-Ming Dynasty relations), the establishment of official diplomatic relations in 1974, and former Malaysian Prime Minister's interactions with Chinese leaders.

Kong $\mathrm{Zi}$ Institute is led by two directors, one each from China and Malaysia. The China director answers to Hanban while the Malaysian director answers to the Vice Chancellor of University of Malaya. Based on the observation of one of the authors here, the two sides share same goals in most aspects but do hold different perspectives on certain matters including the identification of niche market. At a couple of occasions in which one of the authors attended, the Malaysian director repeatedly reiterated that Kong $\mathrm{Zi}$ Institute is here to serve primarily the needs of local Malays. ${ }^{4}$ In addition, the Malaysia director is also not a Sinologist or someone trained in any humanity or social science discipline. He was an ethnic Malay trained in biological science. This is different from the Confucius Institutes in other countries where local Sinologists or humanities scholars serve as co-directors. ${ }^{5}$ 
To date, while the main attendants of Kong Zi Institute's programmes are university students, the institute has also formed partnerships with the government to train Malay civil servants, such as those from the translation, immigration, tourism and law enforcement agencies. A notable aspect is Chinese language training for military students from the academies run by the Malaysian Defense Ministry. This shows that the Kong Zi Institute has a strong support from the governmental side, which is willing to support it through encouraging its civil servants (including soldiers) to attend its courses. Without such governmental support, the student body size might not be that respectable, at least in the initial years. Moreover, Kong $\mathrm{Zi}$ Institute has been running several Chinese language programmes in other public higher education institutions such as Universiti Sains Malaysia, Universiti Malaysia Sabah and Universiti Pertahanan Nasional Malaysia. All of these are government-run public universities with the student population more likely to be Malay. In one sense, this is a unique arrangement because the Kong Zi Institute in Kuala Lumpur has effectively become a master Confucius Institute that serves several local universities and rendering the necessity to set up more Confucius Institutes less urgent.

This is in contrast to the situation of Confucius Institutes in other Southeast Asian countries, such as Cambodia and Thailand, where a majority of the students have been ethnic Chinese who are eager to learn back their lost "mother tongue." The Malaysian Chinese population, owing to its own efforts to preserve Chineselanguage education, in general does not have strong demand for the services provided by Kong Zi Institute, and it is the Malay and other non-Chinese-speaking groups who will benefit from Chinese language courses of Kong Zi Institute.

While the Malaysian director stressed the basic learning of the language for the non-Chinese, for the China director, the promotion of the Chinese language is only the first step and such a step should eventually lead to "a better understanding of Chinese culture and appreciate the good nature of China" (Chen 2014). For the China director, he would like the Kong $\mathrm{Zi}$ Institute to reach as many people as possible regardless of their ethnic or class backgrounds. Kong $\mathrm{Zi}$ Institute also held many cultural events such as Chinese calligraphy, traditional Chinese music, Mid-Autumn Festival celebration and so on, as a step to resume the image of China as an Asian civilisation. Occasionally, Chinese film screening and singing competitions are held to engage the audience with contemporary China. In conjunction with the 10th Anniversary of World Confucius Institutes events, Kong $\mathrm{Zi}$ Institute held a Mandarin poem competition on two themes: love and patriotism. The competition was divided into two categories, namely the Chinese and non-Chinese contestants. 
As of 2014, Kong Zi Institute employed a total of 12 full time staff including administrative and teaching personnel. Their programmes comprise four aspects: HSK examination, Chinese language programmes, cultural programmes and academic programmes. The teaching materials for language classes are primarily provided by Hanban with slight modification by Kong Zi Institute so as to meet the local needs. Expenses of Kong $\mathrm{Zi}$ Institute is divided between China and Malaysia. The Malaysian partner pays for the utility expenses, the cost of hiring five local administrative staff members and office expenses, whereas Hanban pays for teaching staff's salaries and honorariums, and event expenses.

Two surveys were conducted among students who enrolled in the language courses of Kong Zi Institute (Bong 2014; Zhong 2014). The sampling size of these surveys ranged between 150 and 200 people. Both surveys share similarities in their findings of the motivation for Mandarin learning. Findings of both surveys invariably pointed out that social factors or more specifically making friends are the major driving force for Mandarin learning, followed by career advancement. Few were motivated by their interest in China's politics, economy, society and culture. This finding in general confirms other studies conducted on Malaysian public university students about their motivation in learning a foreign language (Ainol Madziah and Isarji 2009).

Bong's study on Mandarin learning motivation among Malaysian students also indicates a division between ethnic Chinese and non-Chinese in terms of the role of Kong Zi Institute. In general, Chinese respondents had heard about Kong Zi Institute and regarded it as a place to promote Confucianism and Chinese culture, whereas a majority of the non-Chinese had not heard of the institute before, and perceived it as a language centre as well as a symbol of Malaysia-China relations. Yet, despite the ethnic Chinese greater awareness of Kong Zi Institute, Kong Zi Institute has not formed a meaningful way of engaging with the ethnic Chinese communities and organisations. ${ }^{6}$ Perhaps in its own determination of finding a "niche market," Kong Zi Institute has decided that the local ethnic Chinese hardly need any Chinese language training and their programmes therefore have focused on the non-Chinese. In addition, according to an interviewee, there has been a mismatch of what Kong $\mathrm{Zi}$ Institute required and what the University of Malaya could commit to. ${ }^{7}$ The administrative support of the university is far from sufficient. As mentioned before, the Malaysia director and other local support staff has no or poor command of the Chinese language. Hence, the China director and other China-sent teachers have to bear a lot of responsibilities for organising outreach events. It may result in only small-scale events such as campus-oriented activities. Over the last few years, except in 2014, most of the Kong Zi Institute's activities were held on the campus. 
As for the first Confucius Institute set up at a private university (SEGi University), there were less hiccups along the establishment process. The Malaysian side was eager to initiate it with the hope that it would serve as a networking platform for SEGi University with other regional universities that house a Confucius Instistute, which would eventually increase enrollments of the university. 89 The objectives of the establishment share a great deal of similarities with many other Confucius Institutes, but are different from Kong $\mathrm{Zi}$ Institute of the University of Malaya in some aspects namely the strategies and target groups. In the introductory note of Confucius Institute at SEGi University, it addresses Malaysia as a multicultural society and expresses its commitment to strengthen its ties with local schools, various organisations and businesses by providing them with quality Chinese language courses and cultural activities. The same note also indicates that Confucius Institute at SEGi University aspires "to be a centre for Malaysia local businesses, academics and the general public to understand China better." The development of Confucius Institute at SEGi would likely have implications on the future development of Confucius Institute in Malaysia, which remains to be seen.

\section{DIPLOMATIC UNDERTAKINGS AT THE SECONDARY GOVERNMENTAL LEVEL}

While the Confucius Institute endeavour represents a concerted and concentrated effort from China's national government to create a long term cultural impact in Malaysia, there are other aspects of China's cultural diplomacy that are being pursued as well. Here, the article focuses on some rarely-noticed diplomatic undertakings from the provincial or city governments, which tend to focus on cultural and economic initiatives between these local governments in China and the ethnic Chinese social organisations in Malaysia. These secondary ties between China and Malaysia are usually fostered by short visits initiated by local or provincial officials who intend to establish transnational ties and to promote cultural exchange and information sharing.

The relationship is mutually beneficiary, for businesses, academics and educational communities, and the ethnic Chinese community in general. It is not a revival of old ties that were based on kinship and shared dialect, but a creation of new ties based on mutual interests. For China's local governments, ethnic Chinese associations in Southeast Asia provide a transnational networking opportunity and Malaysia has been a preferable destination because of the convenience of shared language - Mandarin. 
As for the local government to local government level, a new yet old opportunity arises for the local Chinese merchants in Malaysia: The role of intermediary between local state elites and China delegates. Malaysian Chinese merchants were encouraged to seek for investment opportunities in and from China. As important intermediaries are forged, many Chinese provincial governments have also developed relations with Malaysian state governments, such as the commercial relationship between Guangxi and Pahang, Guangdong and Melaka, and so forth. In Guangxi, a China-Malaysia Industrial Park was established in the port city of Qinzhou, whereas in Pahang, a Malaysia-China Industrial Park was established in Kuantan, another port city. These two industrial parks have been hailed as platforms where future mutual investment will be drawn into. Both governments have, at least in rhetoric, paid significant attention to the development of these parks, although the Malaysian park has been comparatively slower in its development. ${ }^{10}$ In connection with this, a Chinese consortium, backed up with the capital belonging to the Guangxi provincial authorities, has also acquired a $40 \%$ stake in the Kuantan Port and in the process also injecting significant funds to upgrade the facilities of the port to accommodate greater import/export. However, in early 2016, the sudden increase of export of bauxite to China through the Kuantan Port caused a significant pollution crisis and public outcry, forcing the government to put a ban on the bauxite export, which has continued until today. Despite this episode, the commitments of both the Pahang State Government and Guangxi authorities to cooperate on the dual industrial projects remain firm. A road name is dedicated to Kuantan in Qinzhou, whereas in Kuantan a "Qinzhou day" has been hosted.

Another example of secondary-level governmental tie pertains to the relationship between China's Guangdong province and Malaysia's Melaka state. Melaka features importantly in the narrative of Malaysia-China friendship as this was the place Admiral Cheng Ho of the Ming Dynasty visited in the 15th century. The Melaka State Government has been trying to get more Chinese investment into the Malacca Gateway project, which is another project related to port development. Much of the Chinese investment comes from Guangdong, and Melaka and Guangdong also entered into a sister province-state relationship in 2015. When Premier Li Keqiang of China visited Malaysia in late 2015, he specifically paid a visit to Melaka. Direct flights between Melaka and Guangzhou, the capital of Guangdong also commenced in later 2016. A highly popular theatre series "Impressions," directed by the famed Chinese director Zhang Yimou, selected Melaka as site of its first overseas performance. "Impressions Melaka" began showing in 2018. 
Pulau Pinang established a sister-city relationship with Xiamen in Fujian province in as early as 1993. In July 2016, the state of Sarawak also signed a Memorandum of Understanding with the Fujian province (Borneo Post 2016). This would be another formal state-province relationship after GuangdongMelaka and Guangxi-Pahang. With China's interests in Malaysia extending beyond the focal city of Kuala Lumpur, new consulates have been established in other parts of Malaysia (Pulau Pinang in Northern Peninsular Malaysia, and Sabah, in East Malaysia), with increasing China's cultural and economic presence. An example is the new connection between the Chinese consulate in Sabah, based in Kota Kinabalu, the largest city and state capital of Sabah. The Kota Kinabalu Chinese Chamber of Commerce, one of the earliest Chinese organisations in Sabah has entered a good and positive collaborative relationship with China's consulate, such as organising of dozens of cultural events or performances that were held in recent years - traditional dances and music, acrobatic arts and dances - from troupes and performance groups based in Quanzhou (in Fujian) or Sichuan. The itinerary of the Chinese consular general in Kota Kinabalu since her appointment in January 2015, gave a glimpse of the kind of official and cultural activities she had been engaged in: Meeting with state officials and institutions including ministers, bureaucrats and ruling party leaders or people's representatives, meeting with citizens of China in Sabah, namely China's students, businessmen and officials, and meeting with local Chinese associations, business groups and cultural institutions such as Chinese schools.

\section{CHINA'S CULTURAL CAPITAL AND THE LOCAL CHINESE SOCIETY}

Confucius Institute and other activities of cultural diplomacy therefore present concerted efforts by China's government to promote Chinese culture and strengthen its attractiveness. However, Malaysia is not a place without any elements of existing Chinese culture. In fact, the cultural infrastructure of the Malaysian Chinese society is already well entrenched, with the Chinese mass media, ethnic Chinese associations, and the Chinese language schools and education system serving as the three pillars. Most of these Chinese cultural elements existed long before the People's Republic of China had any conscious soft power or cultural diplomacy, and evidently many of them were actually supported by the rival of China - the Republic of China regime in Taiwan.

Overall, the impact of cultural diplomacy on the ethnic Chinese community in Malaysia is positive; such cultural diplomatic activities are significant in sustaining and legitimating the cultural capital of this community. The rush for 
learning Mandarin has given the local Sinophone community a bigger social space and some opportunities that they had not enjoyed in the past. The cultural explanation of China's economic power has enhanced their confidence in Chinese culture. Consequently, there is also a reassertion of local identity among Malaysian Chinese.

Hence, China's cultural diplomacy may actually complicate the local Chinese institutions and become a competitor. For example, the existence of Kong $\mathrm{Zi}$ Institute sometimes has not always been viewed positively by the existing Chinese-language teaching organisations or institutions. ${ }^{11}$ For example, Mr. Chieng, a founder of a private Mandarin learning centre, welcomed the establishment of Kong Zi Institute at the University of Malaya. He often visited the institute's library for new teaching materials. The centre provided support in terms of teaching personnel and services such as Mandarin test. He personally felt that the influence of Kong $\mathrm{Zi}$ Institute on local communities including the Chinese community is very limited. For him, China in many ways represents a competitor. He had an unhappy experience dealing with Hanban and deemed it a scrupulous competitor. For instance, he had used chang cheng han yu (Great Wall Mandarin), a Chinese language teaching material published by Hanban for years. In the beginning of 2014, Hanban charged a fee of USD10.90 for a set of the material. Three months later, without any notification, Hanban raised the price to USD25.90. The move was perceived by Chieng as a sign of "arrogance" on the part of China's government. In another instance, he said that he was cheated under the Hanban's book-giving scheme. ${ }^{12}$

The unpleasant experiences of Chieng have created mixed feelings towards China. In some ways, he found China as an important source of knowledge and resources for his business operation, but the weak institutions of China which permit loopholes for corruption has convinced him that China has yet to develop admirable qualities as in the United States.

\section{REBRANDING CHINA: CHINA MODEL AND THE CHINESE DREAM}

As mentioned before, apart from culture, political values constitute another soft power resource. While China has not necessarily been aggressively promoting its own brand of politics (unlike the United States with its democracy-spreading missions around the world), the China Model that purportedly sums up China's successes over 40 years of reform may also appeal to many developing countries that have been struggling with reducing poverty and promoting economic growth. 
In this connection, China has undertaken a series of rebranding efforts in changing its images in allaying the fears and political distrust towards China among its neighbours, including Malaysia, and to convince them that China can be an inspiring model for others to emulate and learn. In the celebration of the 40th anniversary of the establishment of Malaysia-China relations in 2014, dozens of events including a nationwide roadshow were carried out with the collaboration of the Embassy of the People's Republic of China and the Malaysian government. The main message that was conveyed by the Chinese officials, especially the then Chinese Ambassador Dr. Huang Huikang, was largely about the return of China to the central stage in the region that offered a new vision. On various occasions, he urged the audience to view China as a progressive entity which is in the stage of departing from an old past towards a new future. In some speeches that were attended by one of the authors or reported in the local newspapers, communism was hardly referred to. The ideology seemed to be regarded as the vision of old China, whereas the new China (after the reform and opening up) holds a vision different from the communist ideology. The new China, depicted by Huang as well as other China's officials, has little interest in channeling its energy and resources to revolution and military activities, which in the past would lead to an economy that was poor and underdeveloped by international standards. The new China, however, pursues peace, prosperity, modernisation and harmonious society, which can be summarised in the notion of "The Chinese Dream." Audience was invited to witness the willingness of China to transform itself towards its new dream:

When the people become rich, the country would become strong. The Chinese Dream reflects the aspiration of Chinese to live in peace and happiness; it also creates opportunities and brings development to the world. The Chinese Dream is not a threat to the world. [Authors' translation; Huang (2014)]

The notion of the Chinese Dream is not just aimed to reduce the fears of the Malaysian government and people towards China, but also to cultivate a sense of empathy among Malaysians towards the political values and transformation efforts of China. On many occasions, Huang stressed that China, just like Malaysia is a developing country, and both have been striving to achieve the status of advanced countries. Often, "the Chinese Dream" was made as equivalent to the Vision 2020 of Malaysia. When China shares the aspiration of becoming strong by economic means, as Malaysians have intended to do, they should not be seen as a threat to the world. As to the political ideology and system, not much has been mentioned in China's officials' speeches. Notions of freedom, justice and equality, which have often been stated by American politicians, are not raised in the Chinese Dream. 
In other words, the Chinese Dream emphasises the aspects of socio-economic development rather than the political ideas or values.

The essential principles and goals that were raised in the Chinese Dream and the context it was formulated resembled the Asian values propagated by the Singaporean government about a decade ago, as well as the Look East Policy of Malaysia launched by former Prime Minister Dr. Mahathir in the 1980s. Both stressed the pursuit of high economic growth and rejected Western values such as liberal democracy, individual rights and political freedom, free speech and so forth. ${ }^{13}$ As for international politics, both countries also commit themselves to the policy of non-intervention. Chinese officials thus attempted to leverage on the similarities in political orientation of both China and Malaysia by linking up China's vision "harmonious society" (he xie she hui) with Malaysia's moderation. The connection between Chinese Dream, China Model and possible development of Southeast Asian political-economic trajectory was noted by an outstanding Indonesian academic, Ignatius Wibowo (2011, 207-208), who argued that:

The combined free market and democracy has been accepted by countries in Southeast Asia only with reluctance and hesitation due to, in part, the rise of China in the past ten years...this success story has attracted the countries of Southeast Asia... China's soft power comes from its culture and its cooperation and participation in ASEAN related multilateralism.

Furthermore, as "ASEAN countries in search of development model" and was "inspired by China's ability to maintain high economic growth with illiberal politics" after the 1997 financial crisis, ASEAN members have shifted their development strategy from one based on free market and democracy to one based on semi-free market and illiberal political system (Wibowo 2011, 220-221).

In connection with making the China Model and Chinese Dream appealing to its neighbours, China also projects new images such as being "a friendly neighbour, a trustworthy friend and a reliable partner" of Malaysians. ${ }^{14}$ On some occasions, China's officials go further to assert that the countries outside of the region, often referring to the United States, should stay away from regional affairs. It expresses the intention of building or recovering the bonding ties with neighbouring countries like Malaysia based on historical connection and regional neighbourhood. An abbreviated official narrative of Malaysia-China encounters has been formed in the rebranding process, which has been widely used by the local media as the background information for most write-ups of Malaysia-China events. The events highlighted in the narrative include the official expedition of Ming Dynasty's Admiral Cheng Ho to Melaka and the visionary move of the 
second Prime Minister Tun Abdul Razak in taking the bold step to forge diplomatic ties with China in 1974. Other past events and memories, which are deemed unfavourable to strengthening the ties, have been intentionally played down.

\section{CONCLUSION: ASSESSING MALAYSIAN'S PERCEPTIONS OF CHINA}

From 2013 to 2015, the Pew Research Centre, the global public opinion polling firm, reported that in consecutive years Malaysians have viewed China positively, especially in contrast to the United States. The positive image of China was reconfirmed again in a survey research conducted by one of the co-authors of this article, in April 2016. Coupled with the celebration of the 40th Anniversary of Diplomatic Relationship in 2014, it seemed like at least up until 2016-2017, China generally enjoyed a good image in Malaysia, notwithstanding the ongoing issue of overlapping claims in the South China Sea, the controversy associated with former Ambassador Huang Huikang's visit to Petaling Street, and the increasingly critical comments made by certain civil society and the then opposition leaders regarding several Chinese mega projects such as the East Coast Rail Link (ECRL) and the Forest City. ${ }^{15}$ However, the image of China definitely suffered somewhat before and during the May 2018 elections, when the issue of Chinese investment became a subject of controversy. Some of the projects financed and backed by China were seen as too costly and contributing to the future financial burden of Malaysia, and even worse that they could be related to the alleged corruption of the previous Prime Minister Dato' Sri Mohd Najib bin Tun Abdul Razak. However, despite these challenges and after the new government has taken steps to remediate some of these issues associated with China-backed projects while maintaining cordial diplomatic relations with China, in general Malaysia-China relations have remained overall positive.

Has the cultural diplomacy efforts promoted by China over the years contributed to the positive image of China? The extensive analysis of the efforts made by China in this article suggest that the Chinese government and officials do believe in the efficacy of the Confucius Institute and cultural diplomacy to enhance the soft power of China, and certainly one cannot discount that these efforts overall did contribute to the positive image of China. However, it would be hard to argue that it is the only factor too. For instance, that China has a positive image compared to the United States could be to a large extent a function of other factors. For instance, for the Malay-Muslim majority of the country, anti-American sentiments are tied to the alleged anti-Islam (and Christian crusader disguised as democracy promoter) image of the United States. ${ }^{16}$ In connection with this, the presentation of 
China as a rising superpower and counterbalance to the United States hegemony does not necessarily arouse anxieties among this largest segment of the public, despite the constant wariness about the ties between a superpower China and the increasingly more vocal ethnic Chinese minority. For the ethnic Chinese minority, the rise of China, despite certain misgivings about the perceived unfairness of China's business practices, still represents something that is overall very positive to the Chinese community, giving them a sense of pride.

For some Malaysian officials under the previous Barisan Nasional government, they were attracted to the illiberal political system of China instead of the neoliberal agenda - combination of capitalism and democracy propagated by the United States. In recent years, ties between the ruling parties of both countries - the Chinese Communist Party and the Barisan Nasional coalition (until 2018) - have strengthened, and they have cooperated on several fronts including the training of party cadres. Such party-to-party exchanges certainly would add strengths to China's exercise in soft power (Ngeow 2017).

Hence, while there are certainly impacts coming from the efforts of China's cultural diplomacy in raising the positive image of China, one should take note that Malaysian's positive image of China could have also been caused by other factors not related to China's cultural diplomacy.

\section{ACKNOWLEDGEMENTS}

We thank the Japan Society for the Promotion of Sciences (JSPS) - The "Chinese cultural diplomacy to ASEAN countries" project (code number: 25301018) and the Malaysian Chinese Research Centre of the University of Malaya for funding this research project.

\section{NOTES}

1. For the image of China in Malaysia during this period of time, see Lee (2015).

2. Personal communication with Datuk Azarae (5 August 2014), the then Malaysian Director of the Kong Zi Institute at University of Malaya.

3. BFSU has partnered with over 21 foreign universities or institutions, with most of them in Europe (including such prestigious universities as University of Vienna, University of Rome, University of Sofia, among others). The total number of students under BFSU's Confucius Institute partnerships reached 22,167 in 2014, an increase from 5,914 students in 2010 (Office of Confucius Institute BFSU 2014, 62). 
4. An opening remark of the University of Malaya representative at the official launch of Kong Zi Institute on 26 September 2014. The view was also shared by the then Malaysian Director Datuk Azarae (29-30 November 2014) who posted his message on the Kong $\mathrm{Zi}$ Institute's website: "The primary responsibility for Kong Zi Institute of University of Malaya is the teaching of Mandarin language to non-Chinese speaking citizens particularly among the Malays."

5. Both directors that the authors communicated with have stepped down at the time of submission of this article.

6. Most of the personal communication for this project were carried out in 2014 . In 2016 Kong $\mathrm{Zi}$ Institute seemed to be more proactive in collaborations with local academic bodies such as the Institute of China Studies and the Department of Chinese Studies of the University of Malaya.

7. Personal communication with Ms. Bong in Kuala Lumpur on 8 November 2014.

8. The objectives are printed in the brochures of the Confucius Institute at SEGi University.

9. Personal communication with See Hoon Peow, the Director of the Confucius Institute on 17 June 2014 at SEGi University, Kuala Lumpur.

10. In Malaysia, the new government after the May 2018 elections also has shown an approving attitude towards the Malaysia-China industrial park in Kuantan.

11. In this connection, see the discussion by Ngeow and Tan (2018).

12. Personal communication via telephone with Mr. Chieng in Kuala Lumpur on 11 August 2014.

13. Dominant parties of Malaysia, Singapore and China have ruled the respective countries since independence and the regime change in Malaysia in 2018 had shocked many parties. When the field work of this study was being carried out, the change of government had not yet happened in the three countries. Huang (2014) said China and Malaysia share a lot of similarities in their current status and vision: China's "harmonious world" and Malaysia's moderation.

14. Huang Huikang's speech delivered at the Asia Europe Institute University of Malaya on 20 August 2014. Similar messages were given addressed to the Malaysian audience during a number of occasions, some of which one of the authors had attended.

15. See Ngeow and Tan (2018); Suryadinata (2017).

16. At the time of submission, criticism of China's heavy-handed policy over the Uighur Muslims from the members of Malaysian Muslim society including prominent Islamic leaders and NGOs is rising. In October 2018, the newly elected Malaysian government decided to defy China's request to hand the Uighur detainees to China and allowed them to fly to Turkey. This incident was widely reported in the local media and received strong support from the local Muslim community. In the future, China's unfavourable treatment of Uighur Muslims is likely to be a significant factor that might spur the antiChina sentiments among local Muslims. 


\section{REFERENCES}

Ainol Madziah Zubairi and Isarji $\mathrm{Hj}$ Sarudin. 2009. Motivation to learn a foreign language in Malaysia. GEMA Online Journal of Language Studies 9(2): 73-87.

Awang Sariyan, ed. 2011. Prof. Wu Zhong Yu: 50 tahun dalam pengembangan Bahasa Melayu di China. Putrajaya: Kementerian Pengajian Tinggi Malaysia.

Bong, M.S. 2014. Malaixiya daxue Kong Zi hanyu xueyuan zai Malaixiya huaren shehui beijing xia de fazhan xianzhuang yu zhanwang (The present situation and development prospect of the Kong Zi Institute at University of Malaya under the context of Malaysian Chinese Society). Master's diss., Xiamen University.

Borneo Post. 2016. Sarawak tandatangani MoU dengan Fujian. 18 July. http://www .theborneopost.com/2016/07/18/sarawak-tandatangani-mou-dengan-fujian/ (accessed 20 August 2016).

Chen, Z. 2014. Kong Zi Institute for the teaching of Chinese language: Director's message. http://kongzium.edu.my/?page_id=2161 (accessed 1 September 2014).

Confucius Institute Headquarters (Hanban). 2014. Confucius Institutes worldwide celebrate "Confucius Institute Day". 16 October. Bejing: Confucius Institute Headquarters (Hanban).

2015. Conficius Institute annual development report 2015. Beijing: Confucius Institute Headquarters (Hanban).

Dai, R. 2013. Kong Zi xueyan yu Zhongguo yuyan wenhua waijiao (Confucius Institute and China's language and cultural diplomacy). Shanghai: Shanghai Shehui Kexue Chubanshe.

Guo, J. 2013. Zhongguo wenhua fazhan zhanlue yanjiu (Studies of China's cultural development strategy). Hong Kong: Zhong Hua Shuju.

Hartig, F. 2012. Confucius Institutes and the rise of China. Journal of Chinese Political Science 17(1): 53-76. https://doi.org/10.1007/s11366-011-9178-7

Hsiao, M.H.-H. and A.H. Yang. 2014. Differentiating the politics of dependency: Confucius Institutes in Cambodia and Myanmar. Issues and Studies 50(4): 11-44.

Huang, H. 2014. Zhongguo zhili dazhao xianjingguo, Zhongguo meng 2020 hongyuan xiangtong (China wishes to become a developed state, the connection between China Dream and Vision 2020). 5 May. http://www.nanyang.com/node/621027 (accessed 24 June 2014).

Hughes, C. 2014. Confucius Institutes and the university: Distinguishing the political mission from the cultural. Issues and Studies 50(4): 45-84. https://doi.org/ 10.11619/africa.2014.84_45

Koning, J. and A. Susanto. 2008. Chinese Indonesians and "the rise of China": From business opportunities to questions of identity. In China in the world: Contemporary issues and perspectives, eds. E.K.-K. Yeoh and J.H.-L. Loh, 161-184. Kuala Lumpur: Institute of China Studies, University of Malaya.

Kornphanat, T. 2016. Culture and commerce: China's soft power in Thailand. International Journal of China Studies 7(2): 151-174. 
Kuik, C.-C. 2010. Analyzing Malaysia's changing alignment choices, 1971-89. Jebat 37: 41-74.

Lee, K.H. 2015. Images and the shaping of Malaysia's China policy: 1957-1974. International Journal of China Studies 6(2): 107-128.

Ngeow, C.-B. 2017. Barisan Nasional and the Chinese Communist Party: A case study in China's party-based diplomacy. The China Review 17(1): 53-82.

Ngeow, C.-B. and C.-B. Tan. 2018. Cultural ties and states' interest: Malaysian Chinese and China's rise. In China's rise and Chinese overseas, eds. B.P. Wong and C.-B. Tan, 96-116. Oxon, London: Routledge. https://doi.org/10.4324/ 9781315231952-6

Nguyen, V.C. 2014. Confucius Institutes in the Mekong region: China's soft power or soft border? Issues and Studies 50(4): 85-118.

Nye, J. 1990. Bound to lead: The changing nature of American power. New York: Basic Books.

2005. Soft power: The means to success in world politics. New York: Public Affairs.

2011. The future of power. New York: Public Affairs.

Office of Confucius Institute BFSU. 2014. Annual report 2014, Confucius Institute Beijing Foreign Studies University. Beijing: Office of Confucius Institute.

Pan, S.-Y. 2013. Confucius Institute Project: China's cultural diplomacy and soft power projection. Asian Education and Development Studies 2(1): 22-33. https://doi.org/10.1108/20463161311297608

Paradise, F.J. 2009. China and international harmony: The role of Confucius Institutes in Bolstering Beijing's soft power. Asian Survey 49(4): 647-669. https://doi.org/10.1525/as.2009.49.4.647

Shalins, M. 2014. Confucius Institutes: Academic malware. The Asia-Pacific Journal 12(46): 4220 .

Starr, D. 2009. Chinese language education in Europe: The Confucius Institutes. European Journal of Education 44(1): 65-82. https://doi.org/10.1111/j.1465 $-3435.2008 .01371 . x$

Suryadinata, L. 2017. The rise of China and the Chinese overseas. Singapore: ISEAS. https://doi.org/10.1355/9789814762656

Thung, J.L. 2014. Confucius Institute at the Al-Azhar University, Indonesia: The unseen power of China. Paper presented at the 3rd International Workshop on "China's soft footprints in Southeast Asia", Manila. 4-5 August.

Thuno, M. 2001. Reaching out and incorporating Chinese overseas: The trans-territorial scope of the PRC by the end of the 20th century. The China Quarterly 2001: 910-929. https://doi.org/10.1017/S0009443901000535

Wibowo, I. 2011. China's soft power and neoliberal agenda in Southeast Asia. In Soft power: China's emerging strategy in international politics, ed. Mingjiang Li, 207-224. Plymouth: Lexington Books. 
Wu, Y. 2013. Kong Zi xueyuan yu Zhongguo wenhua de guoji chuanbo (Confucius Institute and the international diffusion of Chinese culture). Hangzhou: Zhejiang Daxue Chubanshe.

Zhong, C. 2014. Malaixiya Kong Zi xueyuan xuesheng hanyu xuexi dongji diaocha yanjiuyi Malaxiya daxue xuesheng weili (A study of the motivation of learning of the students at the Kong Zi Institute at the University of Malaya). Master's diss., Beijing Foreign Studies University. 